\title{
THE ROLE OF HISTAMINE IN DOXORUBICIN AND TENIPOSIDE-INDUCED CARDIOTOXICITY IN DOG AND MOUSE
}

\author{
Nicola Gebbia, Carla Flandina, Gaetano Leto, Francesca Maria Tumminello, \\ Rosario Sanguedolce, Vincenza Candiloro, Mauro Gagliano and Luciano Rausa \\ (Istituto di Farmacologia, Sezione Autonoma di Oncologia Clinica, \\ Policlinico «P. Giaccone », Palermo)
}

\begin{abstract}
In previous studies we reported that teniposide (VM26) induced acute cardiac effects in dogs seem to be related to a release of histamine and that a prior treatment with chlorpheniramine, an $H_{1}$ histamine blocker, prevents the onset of this phenomenon. Since histamine and other vasoactive substances also seem to be involved in doxorubicin (DXR)-induced acute cardiac effects, experiments were undertaken in the aim to prevent, as in the case of VM26, the onset of this phenomenon by administering chlorpheniramine. Since DXR-induced chronic cardiomyopathy also seems to be related to the same mechanisms involved in the onset of acute cardiac effects induced by this drug, additional studies were carried out to investigate whether a long-term treatment with VM26 could induce in mouse alterations of cardiac morphology similar to those of DXR. In addition, because the mouse is known to be extremely insensitive to histamine, further studies were performed to investigate whether DXR or VM26 administration could induce in this animal model a massive histamine release and whether a long-term treatment with high doses of histamine could elicit, similarly to DXR, alterations in cardiac morphology. The results of our experiments demonstrated that DXR $(1.5 \mathrm{mg} / \mathrm{kg}$ i.v.) caused in the dog a massive histamine release and a marked impairment of cardiac inotropism. As previously described for VM26, prior treatments with chlorpheniramine completely prevented this phenomenon. Furthermore, DXR administration, at a dose level able to induce cardiac damage in the mouse $(2.5 \mathrm{mg} / \mathrm{kg}$ i.v. $)$, or that of VM26 $(2 \mathrm{mg} / \mathrm{kg}$ i.v. $)$ failed to induce a massive histamine release. In addition, long-term treatment with VM26 (2 mg/kg i.v.) or high doses of histamine (100 mg/kg i.v.), unlike $\mathbf{D X R}$, did not elicit in this animal alterations of cardiac morphology. Finally, chlorpheniramine $(0.15$ or $0.45 \mathrm{mg} / \mathrm{kg}$ i.v.) did not prevent the onset of chronic cardiomyopathy induced by DXR in mouse. In conclusion, our results show that the role of histamine in the onset of DXR-induced chronic cardiomyopathy, at least in mouse, remains questionable and suggest that this animal, because of its high natural resistance to histamine, is not a suitable experimental model to investigate the cardiovascular pharmacology of drug-induced histamine release.
\end{abstract}

In previous studies $(11,23)$ we reported that teniposide (VM26)-induced early impairment of cardiac inotropism in dog appears to be related to the release of histamine and that pretreatment with chlorpheniramine, a $\mathrm{H}_{1}$ histamine blocker, completely prevents the onset of this phenomenon. Since doxorubicin (DXR)-induced acute cardiac effects seem to be related to histamine release which, in turn, causes a further release of other vasoactive substances $(4,6,14)$, experiments were undertaken with the aim to prevent, as in the case of VM26, the impairment of cardiac inotropism induced by DXR in dog by administering chlorpheniramine. Since DXR-induced chronic cardiomyopathy has also been reported to be related to the same mechanisms involved in the onset of acute cardiac effects induced by this drug $(4,5)$, other studies were carried out to investigate

Acknowledgments: This work was supported by CNR (National Research Council), Project « Oncology », contract no. 85.02323.44. The authors thank Mr. Giuseppe Saso for his technical assistance.

Address for reprint requests: Dr. Nicola Gebbia, Istituto di Farmacologia, Policlinico « P. Giaccone», 90127 Palermo, Italia.

Received October 6, 1986. 
whether long-term treatment with VM26 could induce in mouse, which is one of the most suitable animal models to assess the potential cardiotoxicity of anthracyclines and other antitumor drugs $(2,9,12,21)$, alterations in cardiac morphology similar to those induced by DXR. In addition, because the mouse possesses a very high degree of natural resistance to histamine and may develop tolerance to this substance following repeated treatments $(20,24)$, further studies were performed to determine whether DXR or VM26 administration could induce in this animal model a massive histamine release and whether longterm treatment with high dose of histamine could affect the mouse heart by causing morphologic alterations similar to those induced by DXR.

\section{Material and methods}

Study on DXR-induced acute cardiotoxicity. Five healthy mongrel dogs of both sexes and weighing $15-25 \mathrm{~kg}$ were given DXR, $1.5 \mathrm{mg} / \mathrm{kg}$, as an intravenous 2 min injection of Adriblastina (Farmitalia, Carlo Erba, Milan, Italy). Cardiac parameters were monitored as previously described (10). Briefly, animals were anesthetized with intravenous administration of Pentothal (25 mg/kg). A stiff polyethylene catheter was inserted, via the left carotid, into the left ventricle. Experiments were carried out $24 \mathrm{~h}$ after surgery to avoid the effects induced by Pentothal, which may cause impairment of cardiac inotropism (18). Left ventricular pressure (LVP) was measured by the catheter connected to a pressure transducer (O.T.E. Biomedica, Firenze, Italy). The first derivative of LVP $\left(\mathrm{dP} / \mathrm{dt}_{\max }\right)$ was obtained by a differentiator module (O.T.E. Biomedica, Module 1087). This module was also equipped with a paper polygraph to record LVP and $\mathrm{dP} / \mathrm{dt}$ values. Histamine assay was performed on venous blood samples collected in test tubes containing sodium oxalate. Blood was withdrawn from the saphenous vein at various intervals during the experiments, namely $10 \mathrm{~min}$ before DXR administration, during the phase of the maximal impairment of cardiac contractility, and finally, during the return of cardiac parameters to basal values. Histamine blood levels were measured in whole blood according to the method described by Anton and Sayre (1). Data analysis was computed by Student's $t$ test for paired or, where required, unpaired samples, assuming the 0.05 level of probability as significant.
Prevention of DXR-induced acute cardiotoxicity. These experiments were undertaken similarly to those described above. In addition, each animal was given $0.9 \mathrm{mg} / \mathrm{kg}$ i.v. of chlorpheniramine (Trimeton, Essex, Milan, Italy) $10 \mathrm{~min}$ before administering $1.5 \mathrm{mg} / \mathrm{kg}$ i.v. of DXR.

Histamine blood levels in DXR and VM26treated mice. Female mice (Charles River CD-1 strain COBS) weighing $22 \pm 2 \mathrm{~g}$ were divided in groups of 5 animals each and were given DXR, $2 \mathrm{mg} / \mathrm{kg}$ i.v., or VM26, $2.5 \mathrm{mg} / \mathrm{kg}$ i.v. Controls received saline alone. Animals were sacrificed 5 and 15 min after drug administration. Blood samples were pooled together and histamine assay was performed on whole blood as reported above. Results are the mean $\pm \mathrm{SE}$ of at least 6 separate experiments. Data analysis was computed by analysis of variance, assuming the 0.05 level of probability as significant.

Morphologic evaluation of cardiac lesions in mice. These experiments were carried out on CD-1 female mice weighing $22 \pm 2 \mathrm{~g}$, housed with free access to food and water. Animals were divided into 8 groups of 10-14 animals each and treated as follows: 1st group, control (saline alone); 2nd group, DXR, $2.5 \mathrm{mg} / \mathrm{kg}$ i.v., dissolved in saline (this dose level represents $1 / 8$ of the LD50 and, in our hands, caused morphologic changes in myocardial tissue without any death during the long-term treatment); 3rd group, histamine dihydrochloride (Merck-Schuchartd, Darmstadt, West Germany), $100 \mathrm{mg} / \mathrm{kg}$ i.v. (maximal tolerated dose); 4th group, VM26 (Vumon, Bristol Italiana Sud, Rome, Italy), $2 \mathrm{mg} / \mathrm{kg}$ i.v. (1/8 of the LD50 in the mouse); 5th group, chlorpheniramine, 0.15 $\mathrm{mg} / \mathrm{kg}$ i.v.; 6th group, chlorpheniramine, 0.45 $\mathrm{mg} / \mathrm{kg}$ i.v.; 7th group, chlorpheniramine, 0.15 $\mathrm{mg} / \mathrm{kg}$ i.v., followed $10 \mathrm{~min}$ later by DXR, 2.5 $\mathrm{mg} / \mathrm{kg}$ i.v.; 8th group, chlorpheniramine, 0.45 $\mathrm{mg} / \mathrm{kg}$ i.v., followed $10 \mathrm{~min}$ later by DXR, 2.5 $\mathrm{mg} / \mathrm{kg}$ i.v.

Drugs were given twice a week for 2 weeks followed by a one-week interval without treatment, and then by 3 additional weeks of treatment. Four weeks after the last injections, animals were anesthetized with ether, their thorax opened, and the hearts removed within $1 \mathrm{~min}$. Cardiac morphology was evaluated by light microscopy on heart tissue fixed with $4 \%$ paraformaldehyde in $0.1 \mathrm{M}$ phosphate buffer ( $\mathrm{pH} 7.3$ ), then dehydrated in ethanol and embedded in methacrylate (Histiresin, embedding Kit, LKB, Bromma, Sweden). Median sections of the whole heart, $2 \mu \mathrm{m}$ thick, 
were stained with $1 \%$ toluidine blue in $1 \%$ borax. Morphologic lesions were evaluated in blind and scored according to Bertazzoli et al. (2). Data analysis was computed by the $\chi^{2}$ test assuming the 0.05 level of probability as significant.

\section{Results}

Fig. 1 gives histamine blood levels after administration of DXR in dogs. There was a close relationship between increased histamine blood levels and decreased cardiac contractility. Pretreatment with chlorpheniramine almost completely prevented the acute cardiovascular effects induced by DXR (figs. 2 and 3), although histamine release also occurred in this case (table 1 ). These observations agree with the mechanism of action of antihistamine (8). Furthermore, these data are similar to those obtained in our previous studies with VM26 $(11,23)$.

Table 2 reports the results obtained by light microscopy studies on the morphology of mouse heart treated as previously described in Material and methods. No histologic evidence of cardiac lesions was seen in control groups (fig. 4), whereas the well-known DXR-induced chronic cardiomyopathy occurred in mice treated with this drug (fig. 5). These specific cardiac alterations failed to occur after prolonged treatment with high doses of histamine or VM26. Moreover, administration of chlorpheniramine did not prevent the onset of chronic cardiomyopathy induced by DXR in these animals (figs. 6 and 7).

In addition, DXR administration, at a dose level able to induce in the mouse heart morphologic changes, or that of VM26 failed to induce histamine release (table 3 ). No statistically significant differences were observed between histamine blood level values in control animals versus. those observed in the treated animals.

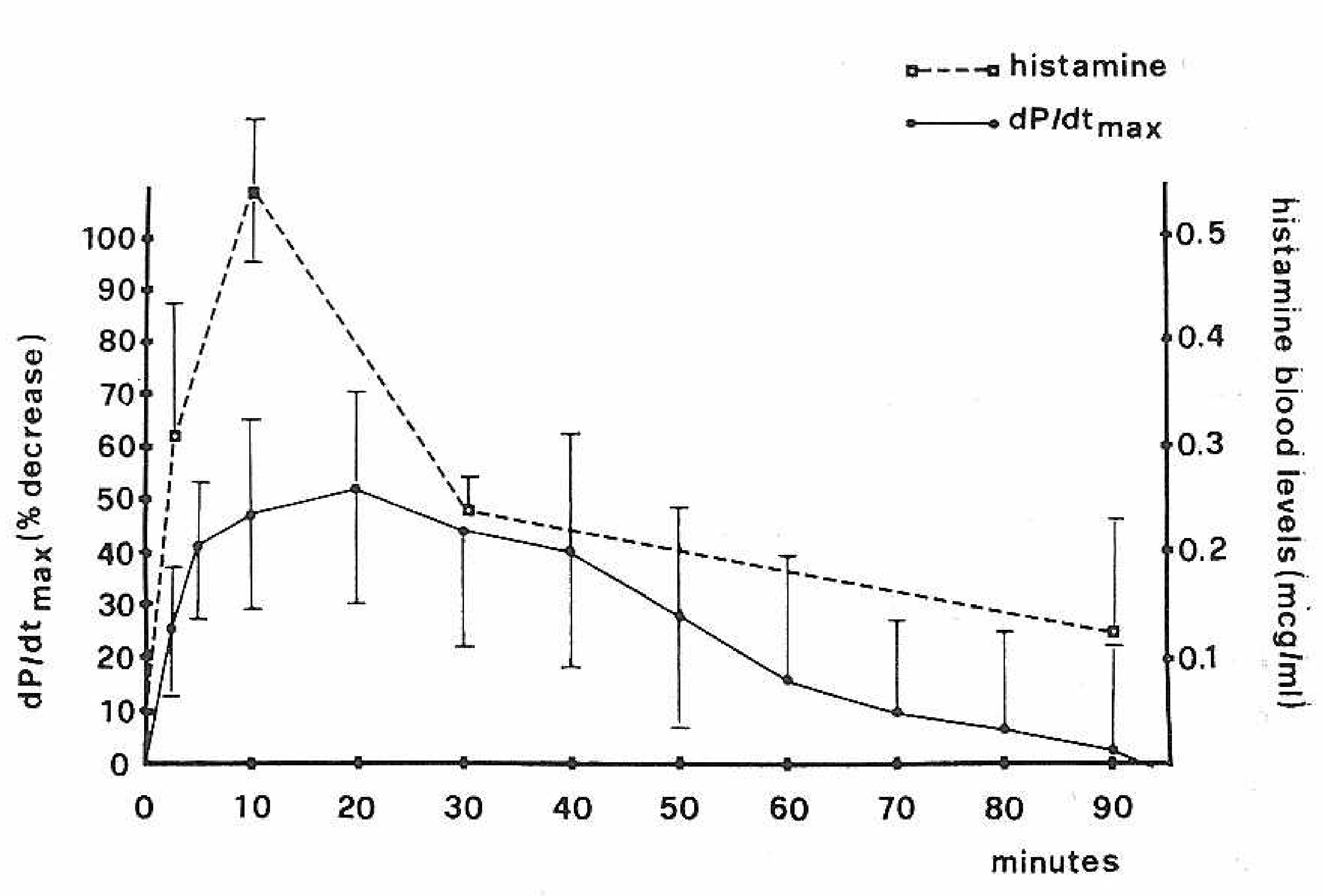

Fig. 1 - Relationship between histamine blood levels: and trend of cardiac contractility $\left(\mathrm{dP} / \mathrm{dt}_{\max }\right)$ in dogs. treated with doxorubicin $(1.5 \mathrm{mg} / \mathrm{kg}$ i.v.). Values represent the mean $\pm \mathrm{SE}$ of five experiments.

Table 1 - Relationship between histamine blood levels $\left(\mu \mathrm{g} / \mathrm{ml}\right.$ ) and cardiac contractility (measured as $\mathrm{dP} / \mathrm{dt}_{\mathrm{max}}$ ) in dogs treated with doxorubicin $(1.5 \mathrm{mg} / \mathrm{kg}$ i.vo) and dogs treated with chlorpheniramine $(0.9 \mathrm{mg} / \mathrm{kg}$ i.v.) plus doxorubicin $(1.5 \mathrm{mg} / \mathrm{kg}$ i.v). Values represent the mean $\pm \mathrm{SE}$ of 5 experiments.

\begin{tabular}{llcr}
\hline & \multicolumn{2}{c}{ Histamine blood levels $(\mu \mathrm{g} / \mathrm{ml})$} & $\begin{array}{c}\mathrm{dP} / \mathrm{dt}_{\max } \\
(\% \text { varition })^{1}\end{array}$ \\
\cline { 2 - 3 } & Basal values & After doxorubicin & $-47.4 \pm 17.1$ \\
Doxorubicin & $0.156 \pm 0.05$ & $0.684 \pm 0.2^{2}$ & $+0.76 \pm 14.7^{3}$ \\
Chlorpheniramine + doxorubicin & $0.231 \pm 0.10$ & $0.650 \pm 0.2^{2}$ & \\
\hline
\end{tabular}

${ }^{1}$ Values refer to the time of the maximal depression of $\mathrm{dP} / \mathrm{dt}$ max.

${ }^{2} \mathrm{P}=0.05$ versus basal values (Student's $t$ test for paired samples).

${ }^{3} \mathrm{P}=0.02$ versus doxorubicin (Student's $t$ test for unpaired samples). 
Table 2 - Morphologic evaluation of cardiac lesions found in CD-1 mice chronically treated with histamine, teniposide, chlorpheniramine, or chlorpheniramine + doxorubicin and sacrificed 4 weeks after the last injection.

\begin{tabular}{|c|c|c|c|}
\hline & \multicolumn{2}{|c|}{$\mathrm{MTS}^{1}$} & \multirow{2}{*}{$\begin{array}{l}\text { No. of affected hearts/ } \\
\text { no. of examined hearts }\end{array}$} \\
\hline & Left atrium & Ventricles & \\
\hline Control & 0 & 0 & $0 / 9$ \\
\hline Histamine (100 mg/kg i.v.) & 0 & 0 & $0 / 10$ \\
\hline Teniposide (2 mg/kg i.v.) & 0 & 0 & $0 / 10$ \\
\hline Chlorpheniramine (0.15 mg/kg i.v.) & 0 & 0 & $0 / 11$ \\
\hline Chlorpheniramine $(0.45 \mathrm{mg} / \mathrm{kg}$ i.v. $)$ & 0 & 0 & $0 / 14$ \\
\hline Doxorubicin $^{2}(2.5 \mathrm{mg} / \mathrm{kg}$ i.v. $)$ & 4.46 & 4.15 & $13 / 13$ \\
\hline $\begin{array}{l}\text { Chlorpheniramine }^{2} \\
(2.5 \mathrm{mg} / \mathrm{kg} \text { i.v. })\end{array}$ & 4.46 & 4.43 & $14 / 14$ \\
\hline $\begin{array}{c}\text { Chlorpheniramine }^{2} \\
(2.5 \mathrm{mg} / \mathrm{kg} \text { i.v. })\end{array}$ & 4.73 & 3.71 & $14 / 14$ \\
\hline
\end{tabular}

${ }^{1} \operatorname{MTS}\left(\right.$ mean total score) $=\frac{\Sigma(\mathrm{a} \times \mathrm{b})}{\text { No. of animals }}$.

${ }^{2}$ Statistically significant differences were observed among control and all groups receiving doxorubicin ( $\chi^{2}$ test).

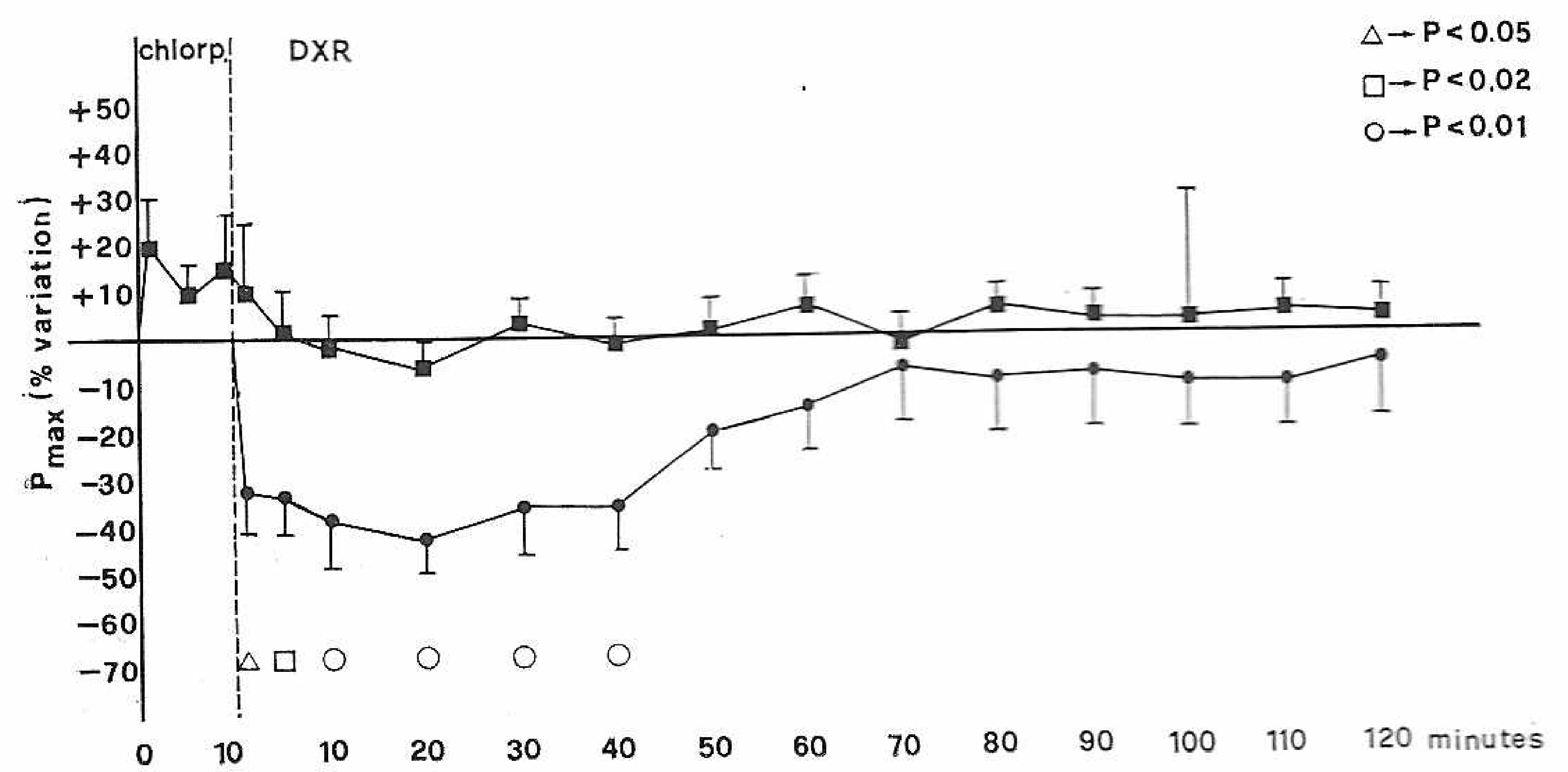

Fig. 2 - Comparison of left ventricular pressure variation, measured as $\mathrm{P}_{\max }$, in dogs treated with chlorpheniramine $(0.9 \mathrm{mg} / \mathrm{kg}$ i.v.) plus doxorubicin (1.5 $\mathrm{mg} / \mathrm{kg}$ i.v.) (四) versus dogs treated with doxorubicin (1.5 mg/kg i.v.) $\bullet$ ). Values represent the mean \pm SE of 5 experiments. Data were computed by Student's $t$ test for unpaired samples.

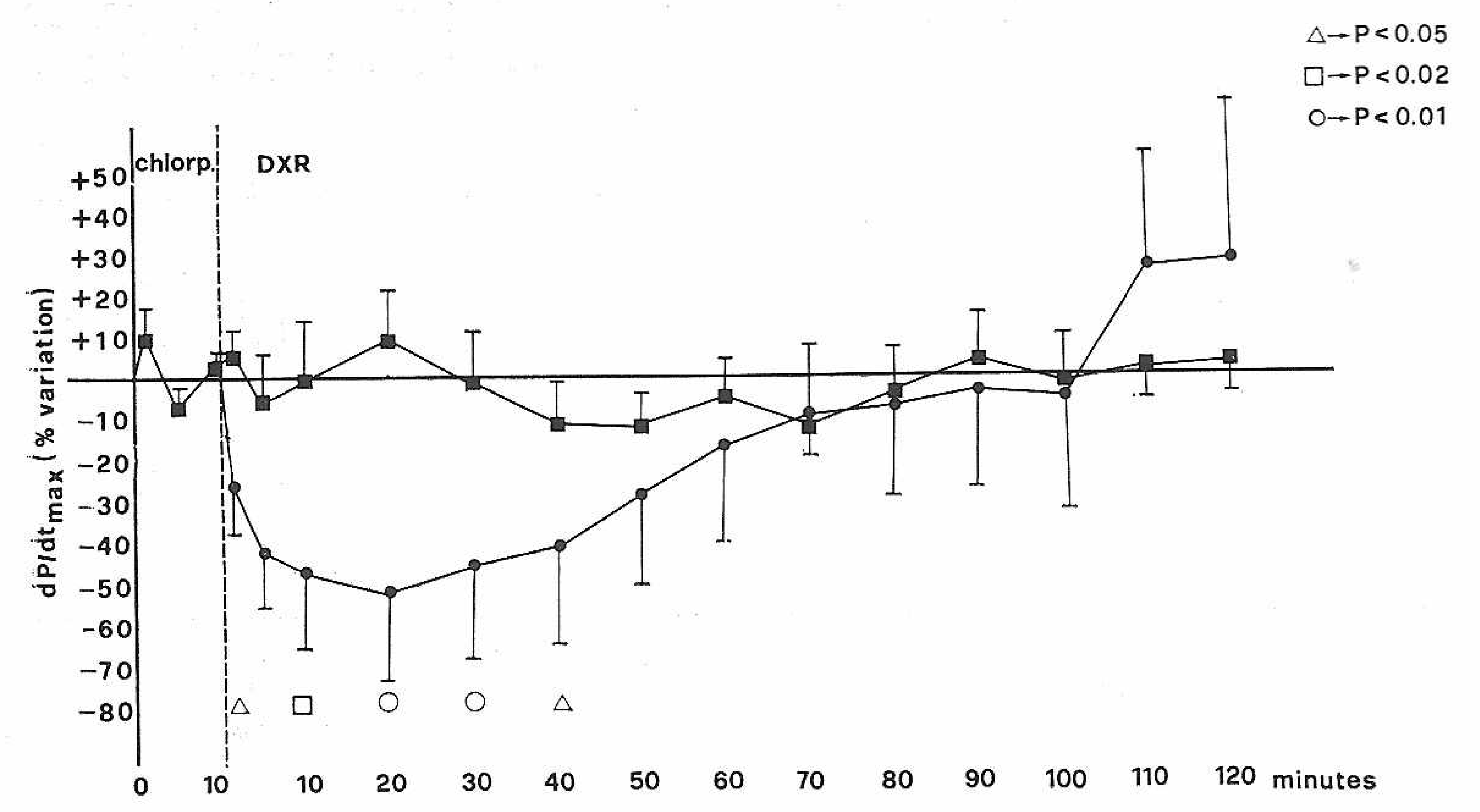

Fig. 3 - Comparison of $\mathrm{dP} / \mathrm{dt}_{\max }$ variation in dogs treated with chlorpheniramine $(0.9 \mathrm{mg} / \mathrm{kg}$ i.v. $)$ plus doxorubicin $(1.5 \mathrm{mg} / \mathrm{kg}$ i.v.) (国) versus dogs treated with doxorubicin ( ). Values represent the mean $\pm \mathrm{SE}$ of 5 experiments. Data were computed by Student's $t$ test for unpaired samples. 


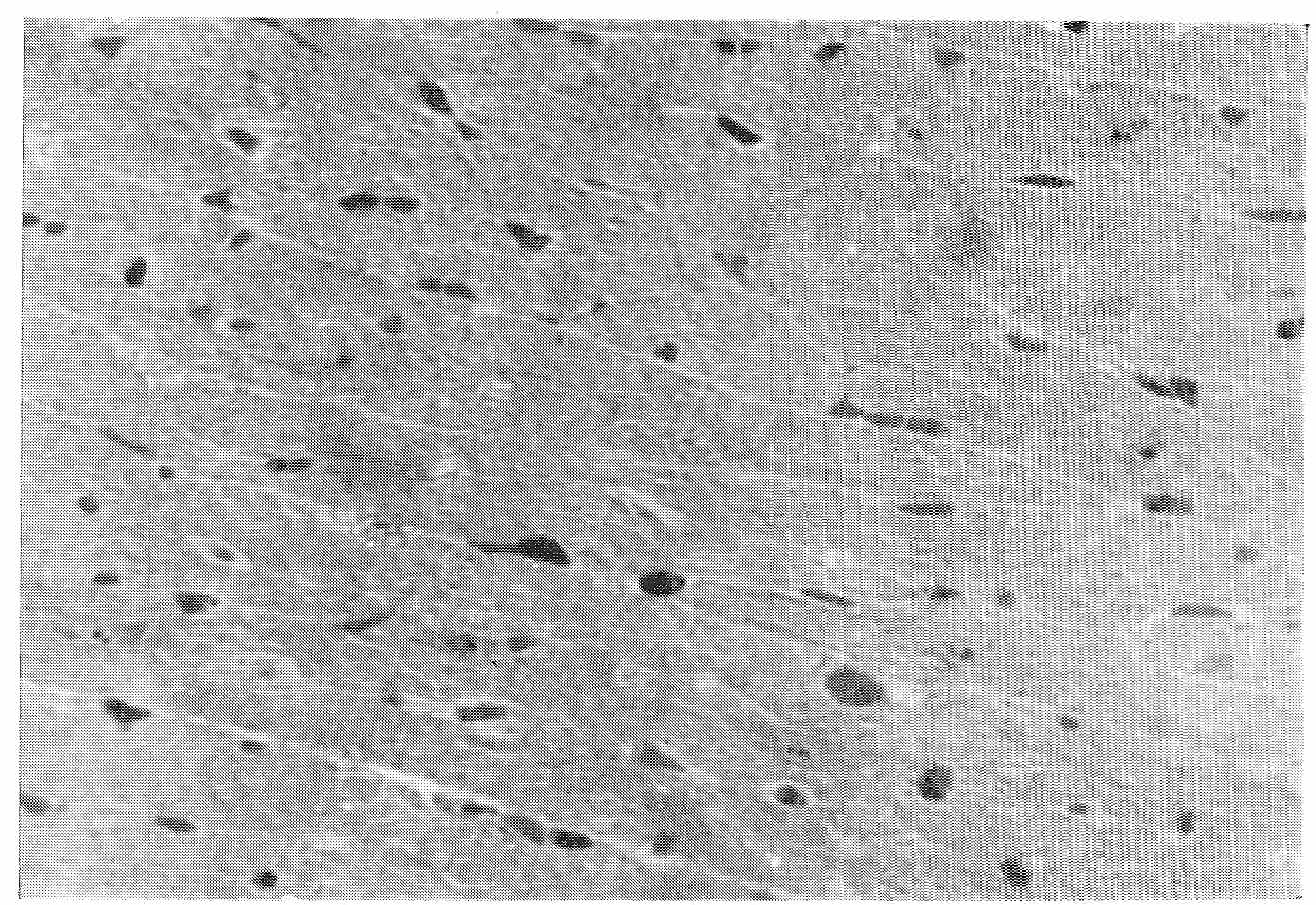

Fig. 4 - Control: left ventricular tissue from a mouse receiving saline i.v.



Fig. 5 - Left ventricular tissue from a mouse treated with doxorubicin $(2.5 \mathrm{mg} / \mathrm{kg}$ i.v. $)$ twice a week for five weeks. Arrow, sarcoplasmic vacuolization. Section stained with toluidine blue. (Original magnification $400 \times$ ). 


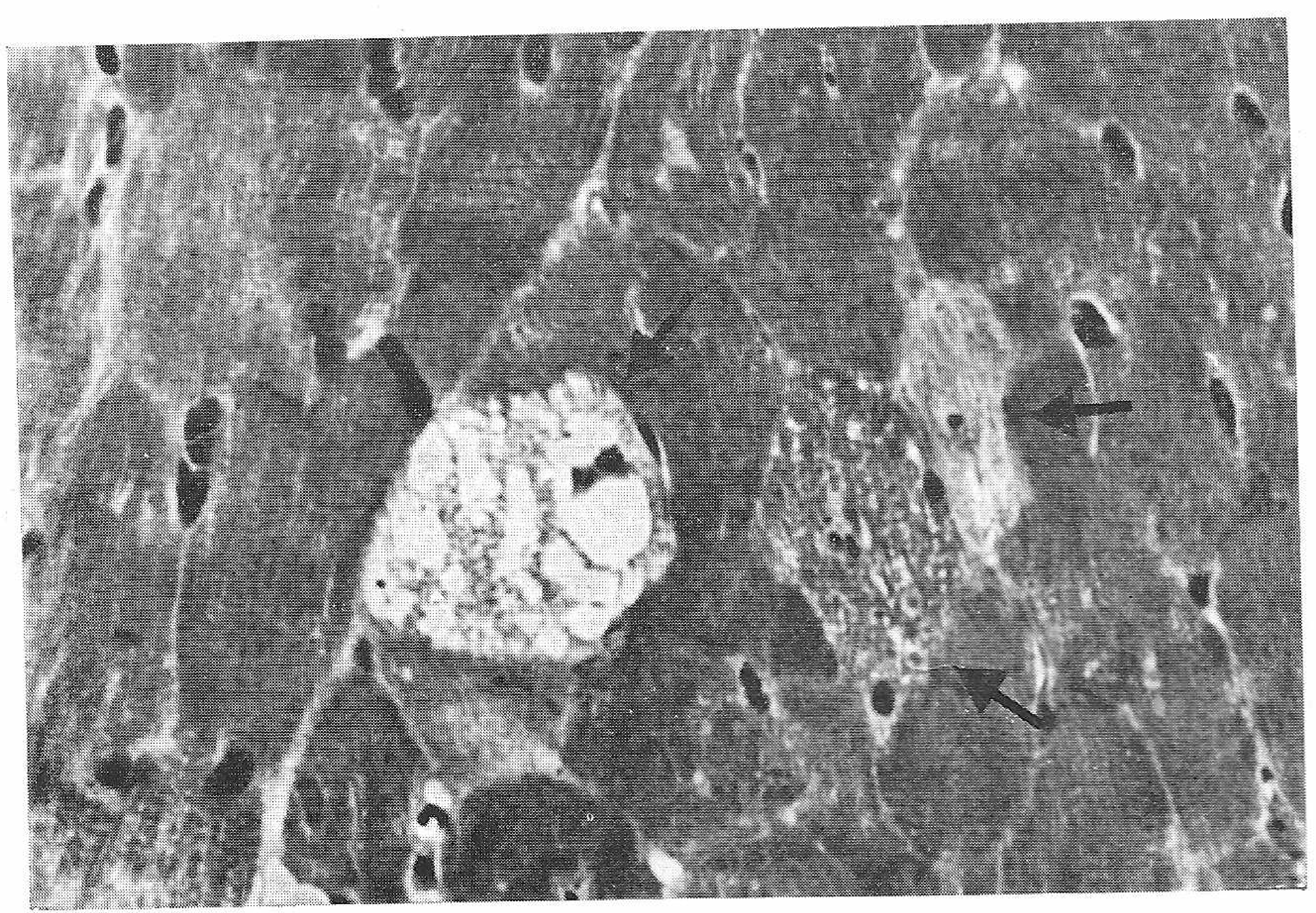

Fig. 6 - Left ventricular tissue from a mouse treated with chlorpheniramine $(0.15 \mathrm{mg} / \mathrm{kg}$ i.v. $)$ plus doxorubicin: Fig. 6 - Left ventricular tissue from a mous $\mathrm{mg} / \mathrm{kg}$ i.v.) twice a week for five weeks. Arrows, sarcoplasmic vacuolization. Section stained with toluidine blue. (Original magnification $400 \times$ ).



Fig. 7 - Right ventricular tissue from a mouse treated with chlorpheniramine $(0.45 \mathrm{mg} / \mathrm{kg}$ i.v.) twice a week for five weeks. Arrow, sarcoplasmic vacuolization. Section stained with toluidine blue. (Original magnification $400 \times)$. 
Table 3 - Histamine blood levels $(\mu \mathrm{g} / \mathrm{ml})$ in mice treated with doxorubicin $(2.5 \mathrm{mg} / \mathrm{kg}$ i.v. $)$ or teniposide (2 $\mathrm{mg} / \mathrm{kg}$ i.v.) and sacrificed 5 and $15 \mathrm{~min}$ after drug administration.

\begin{tabular}{rccc}
\hline & Control & Doxorubicin & Teniposide \\
\hline 5 min & $0.28 \pm 0.05$ & $0.23 \pm 0.03$ & $0.24 \pm 0.04$ \\
$15 \mathrm{~min}$ & $0.28 \pm 0.06$ & $0.27 \pm 0.05$ & $0.23 \pm 0.03$ \\
\hline
\end{tabular}

Values represent the mean \pm SE of 6 experiments.

No statistically significant differences were observed (analysis of variance).

\section{Discussion}

The current study shows that DXR-induced early impairment of cardiac inotropism in the dog, similarly to that of VM26, may be prevented by administering only a $\mathrm{H}_{1}$ histamine blocker. This finding, in accord with the previous observations of Bristow et al. $(4,6)$, further suggests that histamine release might be the first step of a cascade of events which, in turn, may lead to the onset of acute cardiac effects induced by DXR. In addition, our results and those previously obtained with VM26 further demonstrate that in the dog the $\mathrm{H}_{1}$ cardiac receptors mediate the negative inotropic effects of histamine released by these drugs. Although $\mathrm{H}_{2}$ receptors have been reported to play an important role in the overall cardiovascular response to histamine (22), the specific cardiac actions mediated by these receptors in dog heart still need to be clarified (16). However, our data suggest that, at least in dog heart, $\mathrm{H}_{2}$ receptors do not have predominant cardiovascular effects, since by blocking only $\mathrm{H}_{1}$ receptors the negative inotropic effects induced by histamine were avoided, and any positive inotropic effect did not occur.

Although these data do not rule out the involvement of histamine and that of other vasoactive substances in DXR-induced chronic cardiomyopathy in dogs, our long-term studies on mouse heart question its role in the onset of this phenomenon. In fact, DXR administration, at a dose level able to induce cardiac damages, or that of VM26, failed to cause a massive histamine release in this animal model. In addition, long-term administration of high doses of histamine, unlike DXR, did not cause any structural alteration in cardiac morphology.
The high degree of natural resistance to histamine possessed by the mouse and/or the onset of tolerance to this substance $(20,24)$ might account for its ineffectiveness in causing cardiac damages similar to those described in rabbit (15). Furthermore, the data obtained in rabbit refer to short-term experiments. It is possible that the slight cardiac alterations found by these authors were reversible, and that we were unable to find these alterations because of the onset of tolerance following the prolonged treatment we carried out. This last hypothesis is supported by the previous findings of Branwood and Pham (3), who found that intramuscular injections of histamine caused in the atria of albino mouse ultrastructural changes in a small number of cells which, in contrast, did not occur when the treatment was interrupted for 2 weeks and then was followed by a second series of histamine injections. However, it should be noted that the slight cardiac changes reported by all these authors seemed to be specific and, in any case, they appeared to be different from those induced by DXR. Thus, all these observations strongly suggest that, at least in mouse, other mechanisms such as free-radicals production (7) and/or lysosomal changes induced by DXR (13, 25) might be involved in the onset of chronic cardiomyopathy induced by this drug.

These issues are further supported by the results of our experiments with VM26. This drug did not induce in mouse any alteration in cardiac morphology. Interestingly, our previous study (23) demonstrated that VM26, unlike DXR, inhibited in vivo free-radicals production. Furthermore, the drug did not induce any alteration in cardiac lysosomes (unpublished data). In this regard, it is noteworthy that, although acute cardiovascular effects following therapy with VM26 have been reported (17), to date no chronic cardiotoxicity clearly related to this drug has been described.

In summary our results demonstrate that the role of histamine in the onset of DXR-induced chronic cardiomyopathy in mouse remains questionable and it needs to be better assessed. The occurrence of DXR-induced cardiotoxicity in mice, which are extremely insensitive to histamine, suggests that other mechanism(s) might be involved in the onset of this phenomenon, even if histamine release might still be considered as mainly responsible for acute cardiotoxic effects, as rarely seen with this drug $(20,28)$, or, more commonly, with VM26 $(26,27)$ in clinical practice. This issue might also explain the failure of chlorpheniramine to prevent the onset of chronic cardiomyopathy due to DXR. These data also 
suggest that the mouse, because of its high natural resistance to histamine, is not a suitable experimental model to investigate the cardiovascular pharmacology of drug-induced histamine release.

Ruolo dell'istamina nell'insorgenza della cardiotossicità indotta da doxorubicina e teniposide nel cane e nel topo

In precedenti lavori abbiamo potuto evidenziare che gli effetti cardiotossici acuti indotti dal teniposide (VM26) nel cane sembrano molto verosimilmente dovuti ad un massivo rilascio di istamina e che il pretrattamento con clorfeniramina, un antistaminico che blocca selettivamente i recettori $\mathrm{H}_{1}$, previene del tutto l'insorgenza di tale fenomeno. Poiché alcuni dati della letteratura suggeriscono che anche la cardiotossicità acuita da doxorubicina (DXR) sia dovuta ad un rilascio di istamina e di altre sostanze vasoattive, sono stati condotti alcuni esperimenti nel cane allo scopo di prevenire l'insorgenza di tale fenomeno somministrando, come nel caso del VM26, clorfeniramina. Inoltre, poiché è stato suggerito che gli stessi meccanismi coinvolti nell'insorgenza della cardiotossicità acuita da DXR, potrebbero essere responsabili anche dell'insorgenza della cardiomiopatia cronica indotta da tale farmaco, ulteriori studi sono stati effettuati nel topo per stabilire se la somministrazione cronica di VM26 può indurre in tale modello sperimentale delle alterazioni della morfologia cardiaca simili a quelle

\section{References}

1. Anton H.A., Sayre D.: A modified fluorometric procedure for tissue histamine and its distribution in various animals. J. Pharmacol. Exp. Ther., 166: 285-289, 1969.

2. Bertazzoli C., Bellini O., Magrini U., Tosana M.G.: Quantitative experimental evaluation of adriamycin cardiotoxicity in the mouse. Cancer Treat. Rep., 63: 1877-1883, 1979.

3. Branwood A.W., Pham T.D.: The ubiquitous effects of histamine phosphate on the atria of the albino mouse. Lab. Invest., 31: 602-608, 1974.

4. Bristow M.R., Scott Sageman W., Scott R.H., Billingham M.E., Bowden R.E., Kernoff R.S., Snidow G.H., Daniels J.R.: Acute and chronic cardiovascular effects of doxorubicin in the dog: the cardiovascular pharmacology of drug-induced histamine release. J. Cardiovasc. Pharmacol., 2: 487-515, 1980.

5. Bristow M.R., Minobe W.A., Billingham M.E., Marmor J.B., Johnson G.A., Ishimoto B.M., Scott Sageman W., Daniels J.R.: Anthracyclines-associated cardiac and renal damage in rabbits. Evidence for mediation by vasoactive substances. Lab. Invest., 45: 157-161, 1981.

6. Bristow M.R., Kantrowitz N.E., Douglas Harrison W., Minobe W.A., Scott Sageman W., Billingham indotte dalla DXR. Infine, poiché il topo possiede notoriamente una elevata resistenza naturale all'istamina, sono stati condotti degli esperimenti nel tentativo di stabilire se la somministrazione di DXR o quella di VM26 causino in questo animale un rilascio di istamina o se la somministrazione cronica di alte dosi di tale mediatore possa indurre, sempre in tale modello animale, danni morfologici simili a quelli descritti per la DXR. I nostri risultati hanno evidenziato che esiste una stretta correlazione tra rilascio di istamina nel cane a seguito della somministrazione di DXR (1.5 mg/kg i.v.) e diminuzione dell'inotropismo cardiaco. Inoltre, come nel caso del VM26, la comparsa di tale effetto può essere evitata somministrando clorfeniramina $(0.9 \mathrm{mg} / \mathrm{kg}$ i.v.). La somministrazione cronica di VM26 ( $2 \mathrm{mg} / \mathrm{kg}$ i.v.) o di alte dosi di istamina $(100 \mathrm{mg} / \mathrm{kg}$ i.v.) non causano nel topo alcuma alterazione della morfologia cardiaca. D'altra parte la somministrazione di DXR, a dosi che inducono un danno cardiaco, o di VM26 non determinano nel topo alcuna liberazione di istamina e il pretrattamento con l'antistaminico non evita in questi animali la comparsa della cardiotossicità cronica da DXR. I dati da noi ottenuti in definitiva se da una parte confermano il ruolo dell'istamina nell'insorgenza della cardiotossicità acuta da $\mathrm{DXR}$, dall'altra mettono in dubbio che, almeno nel topo, tale sostanza possa essere determinante nell'insorgenza della cardiotossicità cronica da $\mathbb{D X R}$. $\mathbb{E}$ comunque da sottolineare che il topo, a causa della sua elevata resistenza naturale all'istamina, non sembra un modello sperimentale molto valido per lo studio degli effetti cardiovascolari dei farmaci che inducono una liberazione di tale mediatore.
M.E.: Mediation of subacute anthracycline cardiotoxicity in rabbits by cardiac histamine relase. J. Cardiovasc. Pharmacol., 5: 913-919, 1983.

7. Doroshow J.H.: Effect of anthracycline antibiotics on oxygen radical formation in rat heart. Cancer Res., 43: 460-472, 1983.

8. Douglas W.W.: Histamine and 5-hydroxytriptamine (Serotonine) and their antagonists. In: The Pharmacological Basis of Therapeutics, Goodman L., Gilman A. (eds.), p. 609, Sixth Edition. Mac Millan, New York, 1980.

9. Dusonchet L., Crosta L., Bellini O., Flandina C., Palmeri S., Valvo F., Rausa L.: The influence of multiple treatment with doxorubicin or 4'-deoxydoxorubicin on the DNA synthesis and morphology of mouse heart. Int. J. Tissue React., 6: 8189, 1984.

10. Gebbia N., Sanguedolce R., Tumminello F.M. Leto G., Nuccio C., Rausa L.: Cardiac activity of VM26 (teniposide) in the dog. Chemioter. Oncol., 3: $162-167,1980$

11. Gebbia N., Candiloro V., Gagliano M., Leto G., Sanguedolce R., Tumminello F.M., Rausa L.: Cardiovascular activity of VM26. Curr. Chemother. Immunother. Proc., 12th Int. Congr. Chemotherapy, Florence, Italy, July 19-24 1981. 2: 1405 $1407,1981$. 
12. Gebbia N., D’Alessandro N., Messina L., Flandina C., Candiloro V., Leto G., Crescimanno M., Tumminello F.M., Sanguedolce R., Rausa L.: Amsa effects on mouse and rabbit hearts. Cancer Chemother. Pharmacol., 9 (suppl.): 20, 1982.

13. Gebbia N., Leto G., Gagliano M., Tumminello F.M., Rausa L.: Lysosomal alterations in heart and liver of mice treated with doxorubicin. Cancer Chemother. Pharmacol., 15: 26-30, 1985.

14. Herman E.H., Young R.S.K.: Acute cardiovascular alterations induced by low doses of adriamycin, rubidazone and daunorubicin in the anesthetized beagle dog. Cancer Treat. Rep., 63: 1771-1779, 1979.

15. Kantrowitz N.K., Bristow M.R., Minobe W.A., Billingham M.D., Harrison D.C.: Histamine-mediated myocardial damage in rabbits. J. Mol. Cell. Cardiol., 14: 551-556, 1982.

16. Levi R., Owen D.A.A., Trzeciakowski J.: Action of histamine on the heart and vasculature. In: Pharmacology of Histamine Receptors, Ganellin R., Parsons M. (eds.), pp. 236-297, J. Wright, London, 1982.

17. Macbeth F.R.: VM26: Phase I and II studies. Cancer Chemother. Pharinacol., 7: 87-91, 1982.

18. Marshall B.E., Wollman H.: General Anesthetics. In: The Pharmacological Basis of Therapeutics. Goodman L., Gilman A. (eds.), p. 292, Seventh Edition. MacMillan, New York, 1985.

19. Meyers C.E.: Cardiac toxicity. In: Cancer: Principles and Practice of Oncology. De Vita V.T (ed.), p. 1712, J.B. Lippincott, Philadelphia, 1982.

20. Narajano P.: Toxicity of histamine: lethal doses. In: Handbook of Experimental Pharmacology,
Eichler O., Farah A. (eds.), vol. XVIII/1, p. 179, Springer-Verlag, Berlin, Heidelberg, New York, 1966.

21. Perkins W.E., Schroeder R.L., Carrano R.A., Imond A.R.: Myocardial effects of mitoxantrone and doxorubicin in the mouse and guinea pig. Cancer Treat. Rep., 68: 841-847, 1984.

22. Powell J.R., Brody M.J.: Identification and specific blockage of two receptors for histamine in the cardiovascular system. J. Pharmacol. Exp. Ther., 196: 1-14, 1976.

23. Rausa L., D’Alessandro N., Dusonchet L., Gebbia N., Sanguedolce R., Crescimanno M., Crosta L., Flandina C., Leto G., Tumminello F.M.: Pharmacological studies on VM26 (Teniposide). Chemioterapia, 1: 130-136, 1982.

24. Rocha E., Silva M.: Action of histamine upon the circulatory apparatus. In: Handbook of Experimental Pharmacology, Eichler O., Farah A. (eds.), vol. XVIII/1, p. 238, Springer-Verlag, Berlin, Heidelberg, New York, 1966.

25. Singal P.K., Singh R.P.: Lysosomes in adriamycininduced cardiomyopathy: morphological changes. J. Mol. Cell. Cardiol., 16 (suppl.): 13, 1984.

26. Trempe G., Sykes M., Young C., Krakoff I.V.: Phase I trial of the podophyllotoxin derivative VM26. Proc. Am. Ass. Cancer Res., 11: 79, 1970.

27. Wilson W.W., Bull E.: Phase II study of VM26 in advanced non lymphomatous sarcoma. Proc. Am. Ass. Cancer Res., 17: 250, 1976.

28. Worttman J.E., Lucas V.S., Schuster E.: Sudden death during doxorubicin administration. Cancer, 44: 1588-1591, 1979. 